УДК 658.8:338.24

DOI: https://doi.org/10.32782/2520-2200/2020-3-17

Лобза А.B.

доктор фрілософрії в галузі економіки, доцент кафредри кафредри економіки

та соціально-трудових відносин

Університету митної справи та фрінансів

Бикова А.Л.

кандидат економічних наук,

завідувач кафедри кафедри економіки

та соціально-трудових відносин

Університету митної справи та фрінансів

Криша В.В.

студентка

Університету митної справи та фрінансів

Lobza Alla, Bykova Adel, Krysha Valeria

University of Customs and Finance

\author{
АНАЛІЗ ТА ПЕРСПЕКТИВИ РОЗВИТКУ \\ РЕКРУТИНГОВОÏ ДІЯЛЬНОСТІ У СФЕРІ ІТ
}

\title{
ANALYSIS AND OPPORTUNITIES FOR THE DEVELOPMENT OF RECRUITMENT ACTIVITY IN IT
}

У статті розкрито теоретичні аспекти рекрутингу, а також розглянуто становлення рекрутингової діяльності в Україні та використання технологій підбору персоналу. Наведено особливості IT-ринку та специфріку IT-рекрутингу як окремого сегменту управління людськими ресурсами, а також здійснено аналіз проблеми рекрутингу у сфері IT. Крім того, з'ясовано актуальність використання онлайн-платформ для проведення співбесід та проаналізовано опитування рекрутерів щодо зручності проведення онлайн-співбесід. Наголошено на тому, що на сучасному етапі розвитку є вкрай необхідним запровадження соціального рекрутингу та впровадження сучасних методів підбору персоналу.

Ключові слова: рекрутинг, хедхантиг, скринінг, інформаційні технології (IT), соціальний рекрутинг, залучення працівників, співбесіди, онлайн-платформи.

В статье раскрыты теоретические аспекты рекрутинга, а также рассмотрено становление рекрутинговой деятельности в Украине и использование технологий подбора персонала. Приведены особенности IT-рынка и специфика IT-рекрутинга как отдельного сегмента управления человеческими ресурсами, а также осуществлен анализ проблемы рекрутинга в сфере IT. Кроме того, установлена актуальность использования онлайн-платформ для проведения собеседований и проанализирован опрос рекрутеров по удобству проведения онлайн-собеседований. Отмечено, что на современном этапе развития является крайне необходимым введение социального рекрутинга и внедрение современных методов подбора персонала.

Ключевые слова: рекрутинг, хедхантиг, скрининг, информационные технологии (IT), социальный рекрутинг, привлечение работников, собеседования, онлайн-платформы.

Regarding the fact of rapidly changing IT industry in Ukraine, the demand of the most talented and skilled specialists of the information technology field is actively growing. So there is a huge need of the tools for searching personnel in most IT companies to provide them with the effective work and sustainable development. That is why a big competition between IT companies exists nowadays. And recruitment could give a real opportunity of effectively involvement of Ukrainian intellectual and labor potential that lead to the creation of competitive market in Ukraine. In today's world, the term "recruitment" has been replaced by the popular expression "staff recruitment". In general, "recruitment" is an activity to create conditions for filling vacancies in the customer company (employer) by competent professionals who meet the requirements of the customer. Recruitment includes a set of organizational activities carried out in the interests of the customer organization, which consists in the formation and 
submission to the customer of a list of selected, in accordance with the requirements, candidates for this position for further employment. Also the involvement of modern recruiting mechanisms is necessary to have in Ukrainian companies. Almost all of them strive to become a part of the European Union and therefore they must meet certain standards. The same applies to the recruitment. So the main purpose of the article is to consider the formation and development of recruitment in the Ukrainian market, to analyze the use of recruitment technologies and highlight the features of recruitment methods such as headhunting, recruitment and screening. In addition, the purpose of the article is to address the previously unresolved issue of "social recruitment", the use of online platforms for interviews, as well as to analyze the survey of recruiters on the convenience of online interviews. The article does not cover the whole problem of implementing and developing new approaches of the modern recruitment, especially in social networks, however, some problems and ways to solve them outlines and encourages further research in this area.

Key words: recruitment, headhunting, screening, information technology (IT), social recruitment, employee involvement, interviews, online platforms.

Постановка проблеми. У реаліях сучасного світу, зміненого глобалізацією, без перебільшень можна стверджувати, що на зміну індустріальному типу суспільства приходить новий постіндустріальний (інформаційний). Цей тип суспільства передбачає швидкі рішення, кардинальні зміни у світогляді людей, гнучкість та профеесійність, тому саме у період активного розвитку інформаційних технологій управління персоналом почало найактивнішу фразу свого розвитку. При цьому в окремий напрям слід виділити роботу з рекрутингу та ефективного використання кваліфікованих кадрів, знаходження оптимальних моделей підвищення їхньої кваліфікації відповідно до економічних реалій за умов кризи, нових вимог до їхньої діяльності. Беручи до уваги те, що IT-сфрера в Україні нині активно розвивається, на ринку праці постійно зростає потреба у кваліфрікованих фрахівцях саме у сфері інформаційних технологій. Відповідно до цього, в ІТ-компаніях виникає активна необхідність пошуку нових механізмів, інструментів управління персоналом для забезпечення його ефективної роботи, для професійного розвитку та утримання спеціалістів. Між компаніями, що виходять на ринок праці, $є$ величезна конкуренція, а рекрутмент надає реальні можливості ефективного використання українського інтелектуального та трудового потенціалу в межах країни, тим самим він допомагає створювати конкурентоспроможний ринок праці у світовій економіці.

Аналіз останніх досліджень та публікацій. На розв'язання проблем пошуку персоналу звертали увагу у своїх дослідженнях такі зарубіжні вчені, як І. Ансофф, Ф. Беккер, П. Друкер, Г. Кунц, М. Мескон, Ф. Хедоурі, С. О'Донел, Т. Пітерс, Г. Саймон. Ці проблеми цікавили і вітчизняних науковців: С. Бандуру, Д. Богиню, О. Грішнову, В. Данюка, А. Колота, Н. Лук'янченко, В. Нижника, І. Петрову, М. Семикіну, Г. Щокіна, О. Крушельницьку, Л. Балабанову, О. Стельмашенко та інших. Проте це питання потребує додаткових наукових досліджень в умовах інфоорматизації суспільства та інтенсивного розвитку саме IT-сфери, тому цією проблематикою зацікавилися і такі фахівці, як $Є$. Кузьмінов, С. Іванов, П. Решетняк, I. Шевчук та ін.

Мета статті - розглянути становлення та розвиток рекрутингу на українському ринку, проаналізувати використання технологій підбору персоналу та висвітлити особливості методів підбору персоналу (хедхантингу, рекрутингу та скринінгу). Крім того, метою статі є розгляд раніше не розкритого питання стосовно «соціального рекрутингу", використання онлайнплатформ для проведення співбесід, а також аналіз опитування рекрутерів щодо зручності проведення онлайн-співбесід.

Викладення основного матеріалу. Впровадження сучасних механізмів рекрутингу дуже необхідне українським підприємствам, адже майже всі вони сьогодні прагнуть увійти до складу Європи, а отже, повинні відповідати певним стандартам, те саме стосується і підбору персоналу [1].

У сучасному світі на зміну вже звичному терміну «підбір» прийшов популярний вираз «рекрутинг персоналу». Взагалі «рекрутинг» - це діяльність зі створення умов для заповнення вакансій (вакантних робочих місць) у компанії-замовника (роботодавця) компетентними фахівцями, що відповідають за своїми якостями вимогам замовника. Рекрутинг включає комплекс організаційних заходів, що проводяться в інтересах організації-замовника, що полягає у формуванні та поданні замовнику списку відібраних згідно 3 вимогами кандидатів на цю посаду 3 метою подальшого працевлаштування [2].

Перші служби з підбору персоналу почали виникати у країнах Західної Європи: Німеччині, Великій Британії та Франції, які займалися працевлаштуванням та пошуком потрібних кандидатів. Перша американська служба з персоналу, що відома під назвою «біржа зайнятості», вини- 
Розвиток рекрутингу на українському ринку

\begin{tabular}{|c|c|l|}
\hline Назва етапу & Роки & \multicolumn{1}{|c|}{ Характерні риси етапу } \\
\hline Зародження & $1991-1997$ & $\begin{array}{l}\text { Нерозвиненість інфраструктури ринку послуг, найму та підбору } \\
\text { персоналу, відсутність технологічної бази роботи кадрових } \\
\text { агентств в Україні }\end{array}$ \\
\hline Становлення & $1997-1999$ & $\begin{array}{l}\text { Різке збільшення кількості рекрутингових агентств, зміна став- } \\
\text { лення до підбору персоналу за допомогою кадрових агентств } \\
\text { серед вітчизняних підприємств }\end{array}$ \\
\hline Стабілізація & $\begin{array}{l}\text { Використання новітніх технологій 3 підбору персоналу, поява } \\
\text { нових методів рекрутингу, використання соціальних мереж } \\
\text { у підборі персоналу. 3 2001 року число провайдерів кадрових } \\
\text { Послуг почало стрімко зростати - до 2003 року в Україні пра- } \\
\text { цювало вже понад 150 компаній, які позиціонують свій бізнес } \\
\text { у рекрутинговому сегменті. Як правило, це були невеликі орга- } \\
\text { нізації чисельністю 7-15 осіб }\end{array}$ \\
\hline
\end{tabular}

Джерело: розроблено авторами за даними [2]

кла у 1848 році в Бостоні (штат Массачусетс). Проте великі спеціалізовані кадрові агентства вперше з'явилися у США після Великої депресії, особливо після Другої світової війни, коли почався підйом промисловості і стрімко виріс попит на профресійних працівників.

У 1948 році була заснована одна 3 найбільших рекрутингових компаній Manpower. Нині ця компанія має 3600 офрісів у 59 кранах світу, число ії̈ клієнтів перевищує 400 тис. Нині стрімко збільшується попит на висококваліфіковані кадри, готові працювати як на внутрішньому, так і на європейському та міжнародному ринках [3].

Розглядаючи становлення рекрутингової діяльності в Україні, слід зазначити, що перші рекрутингові компанії у нашій державі з'явилися лише в середині 90-х рр. у початковий період становлення ринкових відносин. Цей період не давав рекрутингу розвиватися повною мірою, тому зародження рекрутингових компаній мало деякі специфічні риси, які були зумовлені тим, що Україна опинилася у ситуації вимушеного освоєння багатьох видів бізнесу, оминаючи стадії поступового розвитку [4]. Тому розвиток українського рекрутингового бізнесу пройшов декілька таких етапів (табл. 1).

Розглядаючи рекрутингову діяльність в IT-компаніях, слід відзначити, що Україна посідає 24 місце у світі за привабливістю розроблення програмного забезпечення (ПЗ), тому наші спеціалісти дуже цінуються на міжнародному ринку інформаційних технологій. При цьому українські розробники - на 11 місці у рейтингу 50 країн із найкращими програмістами за версією порталу HackerRank. А фррілансери з України займають сьоме місце за якістю q ефрективністю праці у світі. За даними UNIT.City, український експорт IT-послуг становитиме $\$ 5,4$ млрд у 2020 році і $\$ 8,4$ млрд у 2025 році [4]. Понад 110 міжнародних компаній мають офіси в Україні, з них більша частина знаходиться в Києві. Найбільші партнери - США (45\% компаній), Євросоюз та Ізраїль.

Беручи до уваги вищезгадані фракти, протягом останніх 5 років спостерігаємо різке зростання конкуренції серед компаній, яким усе важче отримати висококваліфікованого співробітника, просто опублікувавши відомості про вакансію на робочих сайтах типу work.ua,

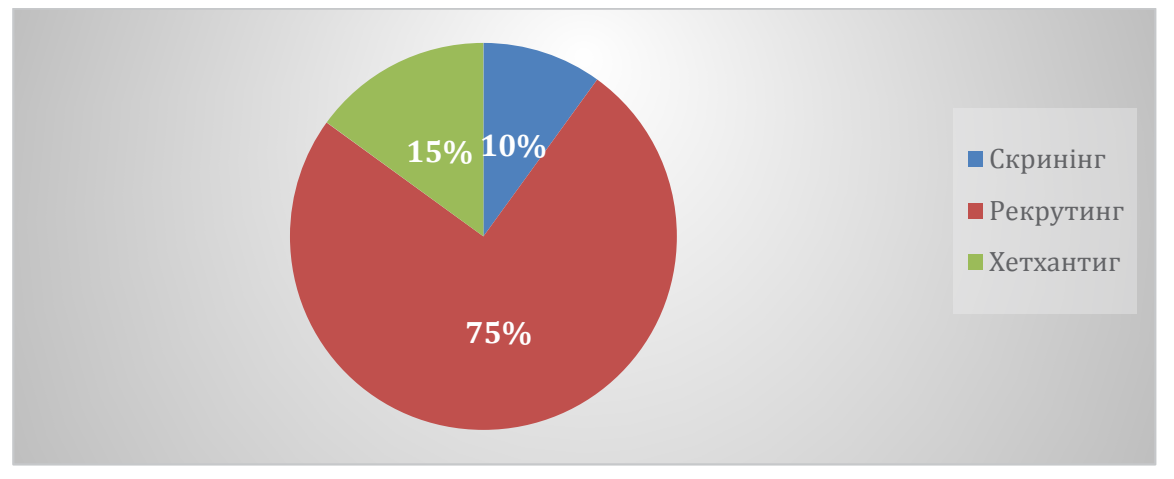

Рис. 1. Використання технологій підбору персоналу

Джерело: розроблено авторами за даними [9] 
rabota.ua, hh.ua тощо. Специфіка IT- рекрутерів полягає ще й у тому, що, на відміну від своїх колег, вони мають володіти специфічною термінологією, бути в курсі актуальних трендів та нових тенденцій, а також розуміти специфіку IT-сорери.

Практика показала, що велика кількість IT-підприємств України, підбираючи персонал, більше використовують рекрутинг (75\%), 15\% скринінг, і тільки 10\% - хедхантинг (рис. 1).

Проаналізувати діаграму, слід зазначити, що рекрутинг $€$ найпопулярнішим методом в IT-індустрії, тоді як скринінг займає $15 \%$, а хетхантинг - лише $10 \%$.

Скринінг - це сучасна технологія підбору кадрів, проте, на відміну від рекрутингу, цей метод передбачає так званий «поверхневий підбір». За цією методикою проводиться технічний відбір за формальними ознаками (вік, стать, освіта, стаж) серед резюме, розміщених в Інтернеті. Після цього процесу формуються бази кандидатів і відправляються замовникам у відповідь на розміщені ними в Інтернеті вакансії. Скринінг - найдешевший метод підбору персоналу, оскільки не вимагає значних витрат.

Великий відсоток у підборі персоналу займає саме рекрутинг, що являє собою технологію, яка забезпечує пошук кваліфікованих фахівців середньої ланки з урахуванням вимог до особистісних та професійних якостей кандидатів, використовуючи наявні бази кандидатів і надаючи оголошення в 3MI [1].

До сучасних методів належить і хедхантинг, він $€$ досить дорогою, однак досить сучасною технологією підбору персоналу, яка спрямована на залучення конкретних працівників. В Україні не вистачає фрахівців як серед об'єктів пошуку, так і серед самих рекрутерів. Основні відмінності цих технологій підбору персоналу для більш поглибленого їх розуміння наведено у таблиці 2.

Вважається, що у перспективі доцільним $€$ удосконалення теоретичних і практичних аспектів організації хедхантингу [1]. У нинішніх реаліях часто самі кандидати прискіпливо виби- рають компанію, у якій хочуть працювати, орієнтуючись на зміст ї̈ корпоративних сторінок у соцмережах, сайту та інших даних. У нових умовах бізнесу доводиться цілеспрямовано створювати і підтримувати свій HR-бренд, щоб залучити кращих кандидатів. Сильний корпоративний бренд допомагає виділитися серед "ноунейм" - конкурентів - навіть за умови однакової заробітної платні.

Упродовж останніх 5 років змінився і процес пошуку роботи. За даними опитувань, сьогодні понад 80\% кандидатів починають пошук роботи 3 Google. Компанії більше не здатні контролювати процес найму "від і до», через що на перший план виходить їх пізнаваність - бренд роботодавця. За даними дослідження Linkedln, $69 \%$ претендентів не працюватимуть у компанії з поганою репутацією, навіть якщо натепер вони безробітні; 84\% замислюються про звільнення зі своєї нинішньої роботи та перехід в іншу компанію із сильнішою корпоративною культурою; 84\% компаній вважають сильний бренд роботодавця ключемдодосягнення цілей рекрутингу [6].

Для пошуку спеціалістів IT-рекрутери найчастіше використовують такі джерела, як:

- професійні мережі (Linkedln, 23\%);

- рекомендації (19\%);

- корпоративні бази даних (16\%).

Часто для пошуку роботи програмісти використовують такий сайт, як Djinni.co. Це професійна IT-мережа, яка допомагає кандидатам рівня Intern та Junior (тобто тим, що мають мінімальний досвід чи не мають досвіду взагалі) знайти швидко роботу. Послуги найму $€$ безкоштовними, якщо вказана кандидатом заробітна плата не перевищує \$1200. Українські девелопери розробили цю мережу, якою нині активно користується майже весь світ. Крім того, рекрутерами використовується мережа під назвою Dou.ua, де вільно реєструються програмісти з усієї України. Ця платорорма допомагає не тільки у пошуку кандидата, а й в аналізі ринку професій та рівня заробітних плат, що допомагає розрахувати бюджет компанії під час найму працівника.

Таблиця 2

Особливості методів підбору персоналу

\begin{tabular}{|c|c|c|}
\hline ХЕДХАНТИНГ & РЕКРУТИНГ & СКРИНІНГ \\
\hline «Якісний пошук» & «Поглиблений підбір» & $\begin{array}{l}\text { «Поверхневий» підбір } \\
\text { на «масові» позиції }\end{array}$ \\
\hline $\begin{array}{l}\text { Враховує особисті та ділові якості } \\
\text { кандидата. Підбір проводиться з } \\
\text { урахуванням особливостей підпри- } \\
\text { ємства і повним отриманням усіх } \\
\text { даних про кандидата. Підбір ключо- } \\
\text { вих менеджерів і фрахівців. }\end{array}$ & $\begin{array}{l}\text { Підбір по формальними вимо- } \\
\text { гами з урахуванням особли- } \\
\text { востей ділових і особистісних } \\
\text { якостей кандидата. Вибір кращих } \\
\text { із наявних у базі, часто здійсню- } \\
\text { ється через оголошення і ЗМl. }\end{array}$ & $\begin{array}{l}\text { Підбір за формальними } \\
\text { вимогами (освіта, стать, } \\
\text { вік, досвід роботи). } \\
\text { Ймовірність вдалого } \\
\text { закриття вакансії стано- } \\
\text { вить 5-10\% }\end{array}$ \\
\hline
\end{tabular}

Джерело: розроблено авторами на основі даних [5] 


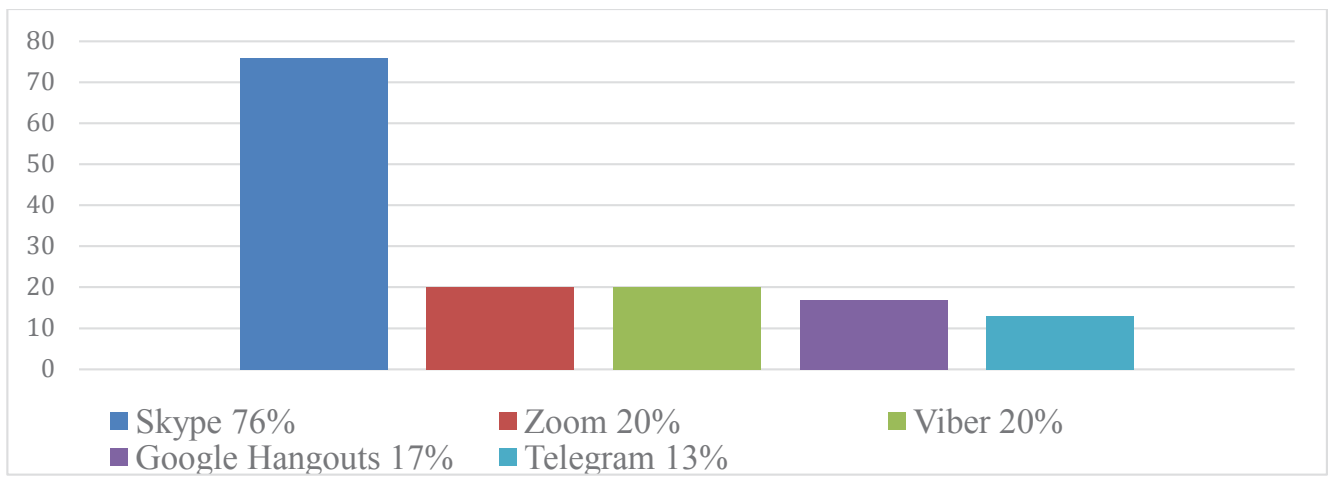

Рис. 2. Використання онлайн-платформ для проведення співбесід Джерело: розроблено авторами на основі даних [8]

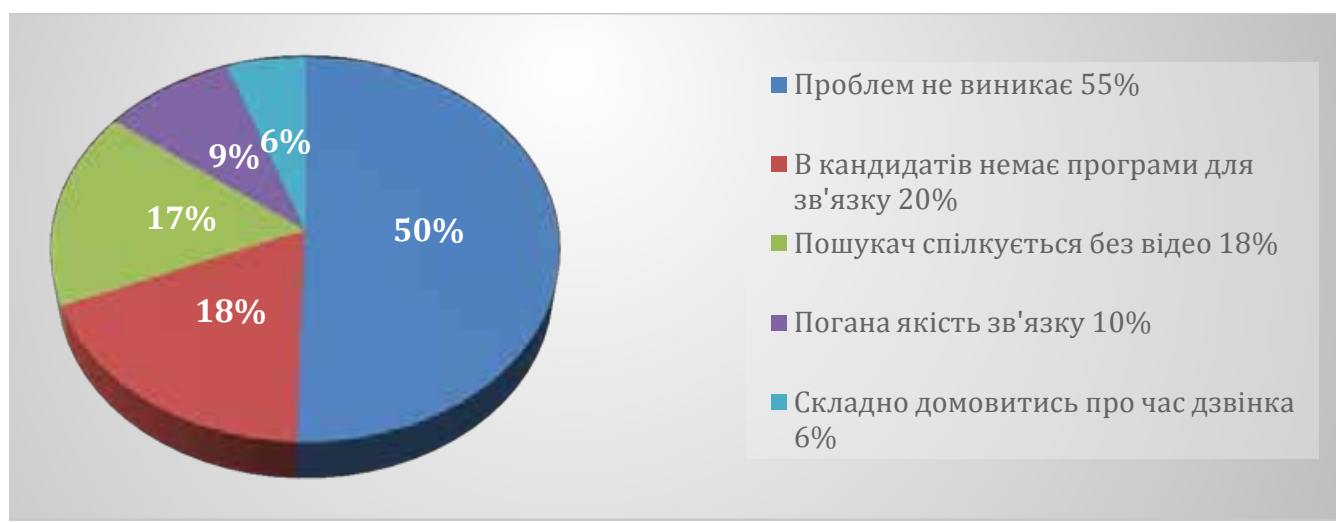

Рис. 3. Опитування щодо зручності проведення онлайн-співбесід

Джерело: розроблено авторами на основі даних [7]

Рідше для пошуку фрахівців використовують сайти для пошуку роботи, професійні ресурси розробників Github, Stackoverflow, Habrahabr (15\%) і соціальні мережі (11,5\%) [9]. Проте, незважаючи на те, що соціальні мережі не займають основного місця у процесі рекрутингової діяльності, у 2020 році сайти типу Facebook, Instagram та Telegram набули неабиякої популярності у пошуку IT-спеціалістів та отримали назву «соціального рекрутингу".

Соціальний рекрутинг являє собою процедуру пошуку і найму претендентів із використанням соціальних платформ, а саме онлайн-сервісів, які слугують відображенню зв'язків між людьми. Подібні сайти з успіхом використовуються багатьма провідними світовими компаніями для реклами й просування власного бренду і залучення кандидатів. У відборі персоналу через соцмережі виділяються дві основні категорії:

- пошук інформації про потенційних працівників;

- застосування медіаресурсів для поширення інформації про вакансії.

Ключовими перевагами соціального рекрутингу можна вважати:
1) скорочення витрат і прискорення процесів підбору персоналу;

2) велику аудиторію платформи (65\% користувачів молодше 35 років);

3) прямий доступ до претендентів і легкість підтримки контактів;

4) можливість аналізу профрілів кандидатів;

5) супутній розвиток позитивного hr-бренду;

6) актуальну базу, що постійно поповнюється.

Крім того, актуалізується питання використання відеоінтерв'ю, особливо останнім часом, через карантинні заходи та обмеження урядом звичайного режиму праці офрфлайн. Близько $60 \%$ організацій звертаються до відеоінтерв'ю для першого знайомства 3 кандидатами. До того ж, деякі програми телеконференцій, серед яких Breezy, Zoom, Montage, Interview4 та Jobvite, мають технічні можливості записувати інтерв'ю. Це полегшує іншим рекрутерам, завдяки перегляду інтерв'ю з вибраними кандидатами, прийняття остаточного рішення щодо їхньої кандидатури.

За останнім опитуванням рекрутерів сайтом Rabota.ua, для онлайн- співбесід рекрутери вибирають Skype, що зображено на рис. 2: 
Проте онлайн-співбесіди ускладнюються подекуди поганим зв'язком, не у всіх кандидатів $€$ відеокамери, а часом і необхідні програми (особливо це стосується підбору робітничих спеціальностей). Однак більшість рекрутерів успішно адаптувалися й не відчувають проблем із проведенням онлайн-співбесід узагалі. Тому на кінець квітня 2020 року ми маємо найбільш актуальні дані, висвітлені на рис. 3:

До карантину дві третини українських рекрутерів активно використовували онлайнспівбесіди. Під час карантину таких уже близько $80 \%$. У період карантину $34 \%$ рекрутерів щодня проводять по декілька онлайнспівбесід: 43\% - декілька на тиждень; 34\% декілька на день; 14\% - декілька за карантин; 9\% - раз за тиждень.

Отже, можемо стверджувати, що останнім часом функції соціальних мереж постійно поліпшуються. Це полегшує рекрутерам пошук кандидатів різних профрілів, i, як результат, це дає набагато ширший спектр пошуку най- кращого кандидата або, як стверджує сучасна HR-спільнота, таланту. Насправді близько 94\% менеджерів із набуття талантів працюють у мережі на сайтах соціальних медіа, щоб відшукати найкращі таланти.

Висновки. Таким чином, рекрутмент - це не просто теорія та не тільки практична система пошуку персоналу. Це серйозний фактор, який багато в чому визначає ситуацію на ринку праці і являє собою потужний інструмент розв'язання багатьох кадрових проблем. Зважаючи на те, що останніми роками наш світ усе більше «діджиталізується", стає прогресивнішим та переходить у режим онлайну у всіх сорерах діяльності, це не могло не торкнутися і сорери рекрутингу. Проведене дослідження не вичерпує усієї проблеми впровадження та розроблення нових підходів щодо сучасного рекрутингу, особливо у соціальних мережах, однак окремі проблеми та шляхи їх вирішення спонукають до продовження досліджень в означеній сорері діяльності.

\section{Список використаних джерел:}

1. Лобза А. В., Клименко С.Ю. Особливості підбору персоналу на сучасних українських підприємствах, тенденції розвитку рекрутингу. Молодий вчений. 2016. №5. C. 87-90. URL: http://nbuv.gov.ua/UJRN/molv_2016_5_25.

2. Купер Д., Робертсон І., Тинлайн Р. Відбір, оренда й найом персоналу: технології тестування з оцінкою. Пер. з анг. І.: ТОВ «Вершина», 2005. 400 с.

3. Ващенко В.В. Дослідження понятійно-категоріального апарату рекрутингу на промислових підприємствах. Теоретичні і практичні аспекти економіки та інтелектуальної власності : Зб. наук. праць. Маріуполь, ДВНЗ «ПДТУ», 2019. Вип. 14. С. 282-285.

4. HR-портал. HR-сообщество и публикации. URL: www.hr-portal.ru (дата звернення: 16.06.2020).

5. Перший великий огляд по українській IT-індустрії, 31 січня 2019. URL: https://rubryka.com/ 2019/01/31/oglyad-it-industriyi-ukrayiny/ (дата звернення: 16.06.2020).

6. Rabota.ua. URL https://rabota.ua/ua/company541675/vacancy6998146 (дата звернення: 16.06.2020).

7. Telegram-канал «Прозора Робота»: цікаві інсайти ринку праці від robota.ua 2020, 3 квітня. URL: https://prohr.rabota.ua/telegram-kanal-prozora-robota-tsikavi-insayti-rinku-pratsi-vid-robota-ua/ (Дата звернення: 16.06.2020).

8. DOU.UA. URL: https://dou.ua/ (дата звернення: 16.06.2020).

\section{References:}

1. Lobza A.V., Klymenko S.Y. (2016) Osoblyvosti pidboru personalu na suchasnyh ukrayinskyh pidpryyemstvah, tendenciyi rozvytku rekrutyngu [Features of personnel selection at modern Ukrainian enterprises, trends in recruitment]. Vol. 5. Pp. 87-90. Available at: http://nbuv.gov.ua/UJRN/ molv_2016_5_25.

2. Kuper D., Rōbertson I., Tynlajn R. Vidbir orendu j najom personalu: texnolohiji testuvannja $z$ ocinkoju [Selection, hiring and hiring of personnel: testing technologies with assessment] Kyiv: TOV "Vershyna», p. 400.

3. Vaschenko V.V. (2019) Doslidzennja ponjatijno-katehorialnoho aparatu rekrutynhu na promyslovyh pidpryjemstvah [Research of conceptual and categorical apparatus of recruitment at industrial enterprises], vol. 14. P. 282-285.

4. HR-portal. HR-soobschestvo s publykacii. Available at: www.hr-portal.ru.

5. Pershyj velykyj ohljad po ukrainskij IT-industrii (2020). Available at: https://rubryka.com/2019/01/31/ oglyad-it-industriyi-ukrayiny.

6. Rabota.ua. Available at: https://rabota.ua/ua/company541675/vacancy6998146.

7. Telegram-kanal «Prozora Robota»: cikavi insajty rynku praci vid robota.ua (2020). Available at: https://prohr.rabota.ua/telegram-kanal-prozora-robota-tsikavi-insayti-rinku-pratsi-vid-robota-ua/.

8. DOU.UA. Available at: https://dou.ua/. 